\title{
Mortality from stomach cancer in Ontario miners
}

\author{
R A Kusiak, A C Ritchie, J Springer, J Muller
}

\section{Abstract}

An excess of mortality from stomach cancer has been found in Ontario gold miners (observed (obs) 104, standardised mortality ratio (SMR) $152,95 \%$ confidence interval $(95 \%$ CI) 125-185) and no excess of stomach cancer could be detected in other miners in Ontario (obs 74, SMR 102, 95\% CI 80-128). The excess of stomach cancer appeared five to 19 years after the miners began gold mining in Ontario. In that interval, similar patterns of excess mortality from stomach cancer were found in miners born in north America (obs 14, SMR 268, CI 147-450) and in miners born outside north America (obs 12, SMR 280, 95\% CI 145-489). Twenty or more years after the miners began mining gold, an excess of mortality from stomach cancer was found in gold miners born outside of north America (obs 41, SMR $160,95 \%$ CI 115-218) but not in gold miners born in north America (obs 37, SMR 113, 95\% CI 80-156). The excess of stomach cancer in gold miners under the age of 60 (obs 45, SMR $167,95 \%$ CI 122-223) seems larger than the excess in gold miners between the ages of 60 and 74 (obs 59, SMR 143, 95\% CI 109-184). Exposures to arsenic, chromium, mineral fibre, diesel emissions, and aluminium powder were considered as possible explanations of the excess of stomach cancer in Ontario gold miners. Exposure to diesel emissions and aluminium powder was rejected as gold miners and uranium miners were exposed to both agents but an excess of stomach cancer was noted only in gold miners. The association between the excess of stomach cancer and the time since the miner began mining gold suggested that duration of exposure to dust in gold mines ought to

Health and Safety Studies Unit, Ontario Ministry of Labour

R A Kusiak

Mount Sinai and Toronto Hospitals

A C Ritchie

Ontario Geological Survey, Ministry of Development and Mines

J Springer

Ontario Ministry of Labour

J Muller (retired) be weighted according to the time since the exposure to dust occurred and that an appropriate time weighting function would be one in the interval five to 19 years after each year of exposure to dust and zero otherwise. A statistically significant association between the relative risk of mortality from stomach cancer and the time weighted duration of exposure to dust in gold mines was found in miners under the age of 60 . Time weighted indices of exposure to chromium and arsenic were formed for each gold miner by time weighting the product of the duration of exposure to dust in a gold mine and the percentages of arsenic and chromium in rocks in that gold mine. Exposure to mineral fibre was measured in terms of the time weighted duration of employment in those gold mines that contain mineralfibre. Astatisticallysignificantassociation between the excess of stomach cancer in gold miners under the age of 60 and the time weighted index of exposure to chromium occurred and no association was found between the excess of stomach cancer and either the time weighted index of exposure to arsenic or the time weighted duration of employment in mines containing mineral fibre. The excess of stomach cancer in gold miners under the age of 60 was better associated with the time weighted index of exposure to chromium than to the time weighted duration of exposure to dust in gold mines. Although the number of cases of gastric cancer that were classified according to the system of Laurén was small, the data suggest that for miners under the age of 60 , exposure to chromium is associated with the development of the intestinal rather than the diffuse type of gastric cancer.

\section{(British Journal of Industrial Medicine 1993;50:117-126)}

Previous studies have shown a statistically significant excess of gastric cancer in Ontario gold miners. ${ }^{2}$ The characteristics of the excess are puzzling: the excess decreases as latency and duration of employment in Ontario gold mines increase. ${ }^{3}$ Also, the excess was larger in younger than in older gold miners. No excess of stomach cancer could be detected in Ontario miners who did not work in Ontario gold mines. 
Ontario gold miners are exposed in the mines to dusts that contain silica, arsenic in the form of arsenopyrite and arsenian sulphides, mineral fibres such as actinolite and tremolite, and trivalent chromium in the form of a chromian mica (fuchsite) and chrome oxide (chromite). Since the mid-1940s most gold miners and all uranium miners in Ontario were exposed to aluminium powder, which was used in an attempt to reduce the incidence of silicosis. Diesel powered equipment was introduced into some Ontario gold mines in the 1960s and always used in Ontario uranium mines and in all but one of the nickel and copper mines. Miners were also exposed to fumes from blasting powders. Many of the miners were born in countries where mortality due to stomach cancer was higher than in Canada and the United States.

In this report, the possibility that the excess of stomach cancer is related to employment in gold mines is reconsidered using information about the amount of exposure to mineral fibre, arsenic, and chromium in individual gold mines.

\section{Materials and methods}

This is a retrospective cohort study of mortality based upon employment and personal data reported by miners to chest clinics that have been operated by provincial government agencies since 1928. Miners are required to attend the clinics to be certified as fit to work in jobs with dust exposure in the Ontario mining industry. Mortality data were obtained from Statistics Canada's mortality database for a 32 year period beginning in 1955. The criteria for inclusion in the study and details about the ascertainment of mortality are described elsewhere. ${ }^{14}$ It has been estimated in a previous study that about $6 \%$ of the deaths in miners in the study were missed. ${ }^{1}$

\section{STATISTICAL METHODS}

The men in this study worked in gold mines, nickel and copper mines, uranium mines, or mines for other ores. For those other than uranium miners, personyears at risk were counted from the year of the first chest examination after 1954 when the miner reported that he had worked at least 60 months in jobs in the mining industry where he was exposed to dust, with at least two weeks of employment in the mining industry in Ontario after 1954. Person-years at risk for men who worked in uranium mines in Ontario were counted from the year of the first chest examination after 1954 when the miner reported having worked for at least two weeks in a uranium mine in Ontario regardless of the duration of any other mining employment. A few men were included in the study because their employment in a uranium mine was reported to the Atomic Energy Control Board by their employer before the men could report their employment history to a chest clinic. For these men person-years were counted from the earliest year of exposure to radon decay products in an Ontario uranium mine. Person-years at risk were counted up to the time of death, age 75 , or the end of the study period, whichever occurred first.

Miners who worked in an asbestos mine or a uranium mine outside of Ontario were excluded to eliminate any risk that might result from exposure to asbestos and because exposures to short lived radon progeny in uranium mines outside of Ontario were not available when the study began. Mortality in men resident in the Province of Ontario was used to calculate the expected number of deaths. Mortality in miners older than 75 was found to be much lower than in Ontario men and the difference was probably due to the underascertainment of deaths in miners in the older age groups.

The hypothesis that the observed number of deaths was greater than expected was tested with the Poisson probability distribution. Poisson regression was also used to determine how several factors jointly affected the mortality of Ontario miners from stomach cancer.

\section{GEOLOGICAL CHARACTERISTICS OF ONTARIO GOLD}

MINES

Studies of the geology of gold mines have shown that the rocks most closely bordering gold ore at a mine fall into one or more of four categories: volcanic rocks of either ultramafic (komatiitic) or mafic (basaltic) composition; and banded iron formation rocks of sedimentary origin or granitic (felsic) rocks that are intrusive plutonic bodies. ${ }^{5}$ Details about the host rock mineralogy of the major gold mines in Ontario are given elsewhere. ${ }^{4}$

\section{WORK PRACTICES IN ONTARIO MINES}

Although improvements in the ventilation of mines were made in the 1930s, the mid-1940s marked the beginning of increased efforts to decrease the level of exposure to silica dust by increasing the amount of ventilation. Almost all gold miners and all uranium miners were exposed to airborne aluminium powder in the changing rooms on the surface before each work shift in the hope of lessening the risk from exposure to silica dust. This practice was begun in the mid-1940s by most gold mines in Ontario. Uranium mining began in Ontario after 1954 and aluminium prophylaxis was used from the outset of operations in those mines. Aluminium prophylaxis was ended in 1979. None of the nickel and copper mines ever used this. The granting of a licence to use aluminium prophylaxis in a mine was contingent upon the implementation of measures to control airborne dust concentrations.

Different explosives have been used in mines in Ontario; TNT was used in the early years and by the 1950s, anfo, a mixture of fuel oil and ammonium 
nitrate was being used by all mines. If the correct amount of oxygen is present, the explosion produces a mixture of carbon dioxide, water, and free nitrogen whereas if there is an excess of oxygen, other compounds including oxides of nitrogen are formed. ${ }^{6}$ In the 1970s, water slurries began to be used. These changes occurred at about the same time in all mines.

Diesel engines were first used underground in Ontario gold mines in 1964. Several gold mines, most uranium mines, and both the large nickel and copper mines in Ontario use diesel powered rubble handling equipment.

EXPOSURE TO ARSENIC, CHROMIUM, AND MINERAL FIBRE A previous report shows the average content of arsenic in major gold mines in Ontario. ${ }^{4}$ This was greater than $1 \%$ in some mines and less than $0.1 \%$ in other mines. The report also noted whether mineral fibre is present in each major gold mine in Ontario.

In our current study, the average amount of chromium in each mine was determined on the basis of analytical data collected by the Ontario Geological Survey, geochemical analyses of rock samples by some mining companies, and the analysis of samples from tailings piles.

\section{TIME WEIGHTED INDICES OF EXPOSURE}

A time weighted index of exposure to arsenic was calculated for each person-year at risk for each gold miner. The duration of exposure to dust in a gold mine during each calendar year was given a weight of one in the 15 year time interval beginning five years after the time of exposure; on either side of that time interval, the duration of exposure was given a weight of zero. Each time weighted duration of exposure was multiplied by the average arsenic content of the rock in the gold mine where the exposure occurred to obtain the time weighted index of exposure to arsenic. In a similar way, the time weighted index of exposure to chromium, the time weighted duration of employment in gold mines containing mineral fibre, and the time weighted duration of exposure to dust in gold mines were calculated.

\section{HISTOLOGY}

Hospitals in which miners with stomach cancer were treated were asked to provide blocks and slides in all cases in which a biopsy or necropsy was performed. The diagnoses were confirmed and the carcinomas were classified according to the systems of Lauren ${ }^{7}$ and the World Health Organisation. ${ }^{8}$

\section{Results}

Table 1 shows that an excess of carcinoma of the stomach could be detected in Ontario gold miners but not in uranium or other miners in Ontario. The total number of deaths from stomach cancer in gold miners was larger than the number expected (observed (obs) 104, standardised mortality ratio (SMR) 152, 95\% confidence interval (95\% CI) 125185). In men who did not work in gold mines, no excess was apparent (obs 74, SMR 102, 95\% CI 80128). Employment in uranium mines or in other mines (mostly nickel and copper) was not associated with excess mortality from stomach cancer. The difference in the relative excess of stomach cancers in gold miners who never mined uranium and uranium miners who also mined gold was not significant $(p=0.5)$.

Table 2 shows mortality from stomach cancer in relation to birth place, type of ore mined in Ontario, attained age, and time since the miner began working in a mine in Ontario. A statistically significant excess of mortality from gastic cancer was evident in gold miners, both those born in north America (obs 51, SMR 133, 95\% CI 99-175) and those born elsewhere (obs 53, SMR 177, 95\% CI 132-231). No excess of gastric cancer was found in miners other than gold miners born in north America (obs 42, SMR 85, 95\% CI 61-114) but an excess was possibly present in non-gold miners born elsewhere (obs 32, SMR 141, 95\% CI 96-199).

Within the 20 years of first employment in the gold mines, the increase in gastric cancer in gold miners born in north America (obs 14, SMR 255, 95\% CI 139-428) and those born elsewhere (obs 12, SMR $270,95 \%$ CI $140-472$ ) was similar and no increase in gastric cancer was evident in miners who did not mine gold, regardless of whether they were born in north America (obs 17, SMR 120, 95\% CI 70-192) or elsewhere (obs 5, SMR 86, 95\% CI 28-200).

No excess of gastric cancer was found in miners born in north America who survived 20 or more years after commencing mining, whether they mined gold (obs 37, SMR 113, 95\% CI 80-156) or other metals (obs 25, SMR 70, 95\% CI 46-104). An excess was evident in miners born outside north America, both those who mined gold (obs 41, SMR 160, 95\% CI

Table 1 Mortality from stomach cancer in gold and uranium miners

\begin{tabular}{|c|c|c|c|c|c|c|c|c|c|c|c|c|}
\hline \multirow{2}{*}{$\begin{array}{l}\text { Uranium } \\
\text { mining } \\
\text { experience }\end{array}$} & \multicolumn{4}{|c|}{ Never gold miner } & \multicolumn{4}{|c|}{ Ever gold miner } & \multicolumn{4}{|l|}{ Total } \\
\hline & $O b s / E x p$ & $S M R$ & $95 \% C I$ & No of men & $O b s / E x p$ & $S M R$ & $95 \% C I$ & No of men & $O b s / E x p$ & $S M R$ & $95 \% C I$ & No of men \\
\hline $\begin{array}{l}\text { Never } \\
\text { Ever } \\
\text { Total }\end{array}$ & $\begin{array}{l}54 / 53 \cdot 68 \\
20 / 18 \cdot 65 \\
74 / 72 \cdot 34\end{array}$ & $\begin{array}{l}101 \\
107 \\
102\end{array}$ & $\begin{array}{l}76-131 \\
66-166 \\
80-128\end{array}$ & $\begin{array}{l}20136 \\
16784 \\
36920\end{array}$ & $\begin{array}{r}79 / 53 \cdot 60 \\
25 / 14 \cdot 63 \\
104 / 68 \cdot 22\end{array}$ & $\begin{array}{l}147 \\
171 \\
152\end{array}$ & $\begin{array}{l}117-184 \\
111-252 \\
125-185\end{array}$ & $\begin{array}{r}11097 \\
6110 \\
17207\end{array}$ & $\begin{array}{c}133 / 107 \cdot 28 \\
45 / 33 \cdot 28 \\
178 / 140 \cdot 56\end{array}$ & $\begin{array}{l}124 \\
135 \\
127\end{array}$ & $\begin{array}{r}104-147 \\
99-181 \\
109-147\end{array}$ & $\begin{array}{l}31233 \\
22894 \\
54127\end{array}$ \\
\hline
\end{tabular}


Table 2. Mortality from stomach cancer in gold miners and other miners: birth place, age and time since first gold mining or other mining

\begin{tabular}{|c|c|c|c|c|c|c|c|c|c|}
\hline \multirow{3}{*}{$\begin{array}{l}\text { Age } \\
\text { groups }\end{array}$} & \multirow[b]{3}{*}{ Latency } & \multicolumn{4}{|c|}{ Never gold miner } & \multicolumn{4}{|c|}{ Ever gold miner } \\
\hline & & \multicolumn{2}{|c|}{ Born in north America } & \multicolumn{2}{|c|}{ Born outside north America } & \multicolumn{2}{|c|}{ Born in north America } & \multicolumn{2}{|c|}{ Born outside north America } \\
\hline & & $O b s / E x p$ & $S M R$ & $O b s / \operatorname{Exp}$ & $S M R$ & $O b s / E x p$ & $S M R$ & $O b s / E x p$ & SMR \\
\hline$<60$ & $\begin{array}{l}<5 \\
5-19 \\
20+ \\
\text { Total }\end{array}$ & $\begin{array}{c}3 / 0 \cdot 71 \\
10 / 10 \cdot 65 \\
12 / 16 \cdot 23 \\
25 / 27 \cdot 58\end{array}$ & $\begin{array}{r}424 \\
94 \\
74 \\
91\end{array}$ & $\begin{array}{c}0 / 0 \cdot 29 \\
2 / 4 \cdot 58 \\
9 / 6 \cdot 28 \\
11 / 11 \cdot 15\end{array}$ & $\begin{array}{r}0 \\
44 \\
143 \\
99\end{array}$ & $\begin{array}{c}0 / 0 \cdot 23 \\
12 / 4 \cdot 20 \\
10 / 12 \cdot 07 \\
22 / 16 \cdot 51\end{array}$ & $\begin{array}{r}0 \\
286 \\
83 \\
133\end{array}$ & $\begin{array}{l}0 / 0 \cdot 13 \\
11 / 3 \cdot 43 \\
12 / 6 \cdot 90 \\
23 / 10 \cdot 46\end{array}$ & $\begin{array}{r}0 \\
321 \\
174 \\
220\end{array}$ \\
\hline $60-74$ & $\begin{array}{l}<5 \\
5-19 \\
20+ \\
\text { Total }\end{array}$ & $\begin{array}{c}1 / 0 \cdot 08 \\
3 / 2 \cdot 71 \\
13 / 19 \cdot 25 \\
17 / 22 \cdot 04\end{array}$ & $\begin{array}{r}1300 \\
111 \\
68 \\
77\end{array}$ & $\begin{array}{c}0 / 0.01 \\
3 / 0.95 \\
18 / 10.61 \\
21 / 11.57\end{array}$ & $\begin{array}{r}0 \\
314 \\
170 \\
181\end{array}$ & $\begin{array}{c}0 / 0.04 \\
2 / 1.02 \\
27 / 20 \cdot 65 \\
29 / 21 \cdot 71\end{array}$ & $\begin{array}{r}0 \\
196 \\
131 \\
134\end{array}$ & $\begin{array}{c}0 / 0.01 \\
1 / 0.86 \\
29 / 18.67 \\
30 / 19.55\end{array}$ & $\begin{array}{r}0 \\
116 \\
155 \\
153\end{array}$ \\
\hline$\leqslant 74$ & $\begin{array}{l}<5 \\
5-19 \\
20+ \\
\text { Total }\end{array}$ & $\begin{array}{c}4 / 0 \cdot 78 \\
13 / 13 \cdot 26 \\
25 / 35 \cdot 48 \\
42 / 49 \cdot 62\end{array}$ & $\begin{array}{r}510 \\
97 \\
70 \\
85\end{array}$ & $\begin{array}{c}0 / 0 \cdot 30 \\
5 / 5 \cdot 53 \\
27 / 16 \cdot 88 \\
32 / 22 \cdot 72\end{array}$ & $\begin{array}{r}0 \\
90 \\
160 \\
141\end{array}$ & $\begin{array}{c}0 / 0 \cdot 27 \\
14 / 5 \cdot 22 \\
37 / 32 \cdot 72 \\
51 / 38 \cdot 22\end{array}$ & $\begin{array}{r}0 \\
268 \\
113 \\
133\end{array}$ & $\begin{array}{c}0 / 0 \cdot 15 \\
12 / 4 \cdot 29 \\
41 / 25 \cdot 57 \\
53 / 30 \cdot 00\end{array}$ & $\begin{array}{r}0 \\
280 \\
160 \\
177\end{array}$ \\
\hline
\end{tabular}

115-218) and in those who worked in other mines (obs 27, SMR 160, 95\% CI 105-233).

The excess of gastric cancer was also dependent upon attained age. It was larger in gold miners under the age of 60 (obs 45, SMR 167, 95\% CI 122-223) than in gold miners between the ages of 60 and 74 (obs 59, SMR 143, 95\% CI 109-184). In miners who mined other metals, no excess of stomach cancer was evident in those younger than 60 (obs 36, SMR 93, $95 \%$ CI 65-129) or in those between the ages of 60 and 74 (obs 38, SMR 113, 95\% CI 80-155).

The average duration of employment underground in gold mines was 9.3 years for miners born in north America and 12.4 years for gold miners who were born elsewhere.

The term mining camp is used to describe a district in which exist a number of mines of similar type. Table 3 shows the mean content of chromium found in different host rocks in four gold mining camps in Ontario as derived from records in PETROC, a database containing geochemical analyses of rock samples collected by the Ontario Geological Survey (OGS). Some of the samples were from rocks within the mines, some from rocks nearby. For comparison, world average amounts of chromium in typical ultramafic, mafic, intermediate, and felsic rock are $2000 \mathrm{ppm}, 100 \mathrm{ppm}, 50 \mathrm{ppm}$, and $25 \mathrm{ppm}$ respectively and average chromium concentrations in shale and granite are $100 \mathrm{ppm}$ and $20 \mathrm{ppm}$ respectively. ${ }^{9}$
Table 4 shows amounts of chromium in samples of rock from Ontario gold, nickel and copper, and some uranium mines and the predominant host rock in the gold mines. The table also shows the year of first operation of the gold mines. The mines in the Sudbury camp are nickel and copper mines, those in the Elliot Lake and Bancroft camps are uranium mines. The others are gold mines. The levels of arsenic and silica and the presence of mineral fibre in each gold mine are shown elsewhere. ${ }^{4}$

The average amount of chromium in an Ontario gold mine was determined by using the amounts of chromium in samples of rocks from the mine whenever such data were available. Otherwise, the average amount of chromium in PETROC's inventory of rock samples of the same geological type as the host rock in the mine and in the same mining camp as the mine were used. There were dozens of gold mines that operated in Ontario but many of these mines were small and operated for only brief periods. Of the 4.3 million man-months that the study group worked in Ontario gold mines, 100000 man-months $(2 \%)$ were in mines where only the camp was indicated in the computerised work history records. When only the camp where the gold mine was located was known, the median concentrations of arsenic and chromium in mines in that camp were used as the most probable levels of exposure to arsenic and chromium.

Table 3 Chromium concentrations (ppm) according to mining camp and host rock

\begin{tabular}{|c|c|c|c|c|c|c|c|c|}
\hline \multirow[b]{2}{*}{ Type of host rock } & \multicolumn{2}{|c|}{ Timmins } & \multicolumn{2}{|c|}{ Kirkland Lake } & \multicolumn{2}{|c|}{ Red Lake } & \multicolumn{2}{|c|}{ Geraldton/Beardmore } \\
\hline & Mean & $\begin{array}{l}\text { Sample } \\
\text { size }\end{array}$ & Mean & $\begin{array}{l}\text { Sample } \\
\text { size }\end{array}$ & Mean & $\begin{array}{l}\text { Sample } \\
\text { size }\end{array}$ & Mean & $\begin{array}{l}\text { Sample } \\
\text { size }\end{array}$ \\
\hline $\begin{array}{l}\text { Basaltic } \\
\text { Felsic } \\
\text { Ultramafic }\end{array}$ & $\begin{array}{r}233 \\
85 \\
2154\end{array}$ & $\begin{array}{r}86 \\
6 \\
39\end{array}$ & $\begin{array}{r}108 \\
94 \\
1801\end{array}$ & $\begin{array}{l}33 \\
13 \\
49\end{array}$ & $\begin{array}{r}258 \\
200 \\
1583\end{array}$ & $\begin{array}{r}241 \\
8 \\
44\end{array}$ & $\begin{array}{r}20 \\
337\end{array}$ & $\begin{array}{l}1 \\
8\end{array}$ \\
\hline Banded iron formation & & & & & & & 60 & 16 \\
\hline
\end{tabular}


Equations of the torm:

$$
\text { Obs/Exp }=\mathrm{i}+\mathrm{aX}
$$

where obs $=$ observed number of stomach cancer deaths, exp = expected number of stomach cancer deaths, $X=$ the exposure variable, and $i$ and $a$ are the calculated regression coefficients, were used to test for associations between the relative excess of mortality from stomach cancer and each exposure.

Table 5 shows that in gold miners under 60 , there were statistically significant associations between mortality from gastric cancer and the time weighted duration of exposure to dust in gold mines and the time weighted index of exposure to chromium but not to the time weighted index of exposure to arsenic or the time weighted duration of employment in gold mines containing mineral fibre. For miners between the ages of 60 and 74, no statistically significant association between gastric cancer mortality and any of these measures was found.

Table 6 shows mortality from stomach cancer in gold miners under 60 . The data suggest that mortality from stomach cancer is more closely associated with the time weighted index of exposure to chromium than with the time weighted duration of employment in gold mines. The Poisson regression

Table 4 Chromium concentrations ( $\mathrm{ppm}$ ) in rock samples from gold, nickel and copper and uranium mines in Ontario

\begin{tabular}{|c|c|c|c|c|c|}
\hline \multirow[b]{2}{*}{ Mine } & \multirow[b]{2}{*}{ Host rock } & \multicolumn{3}{|c|}{ Source of rock sample } & \multirow{2}{*}{$\begin{array}{l}\text { Year of } \\
\text { first operation }\end{array}$} \\
\hline & & PETROC & Tailings & Mining Company & \\
\hline $\begin{array}{l}\text { Timmins camp: } \\
\text { Pamour No3 } \\
\text { Delnite } \\
\text { Buffalo-Ankerite } \\
\text { Ross Mine } \\
\text { Broulan Reef } \\
\text { Pamour No 2 } \\
\text { Pamour No 1 } \\
\text { Coniarium } \\
\text { Hollinger } \\
\text { McIntyre } \\
\text { Dome } \\
\text { Paymaster } \\
\text { Preston East Dome }\end{array}$ & $\begin{array}{l}\text { K } \\
\text { BA } \\
\text { BA } \\
\text { BA } \\
\text { BIF } \\
\text { BA/BIF } \\
\text { BA } \\
\text { BA } \\
\text { BA } \\
\text { BA } \\
\text { BA/K } \\
\text { BA } \\
\text { F }\end{array}$ & 1170 & $\begin{array}{c}308 \\
197 \\
234 \\
149 \\
39 \\
257,146 \\
58 \\
78 \\
\\
169 \\
219\end{array}$ & $\begin{array}{l}165 \\
253\end{array}$ & $\begin{array}{l}1940 \\
1937 \\
1926 \\
1936 \\
1939 \\
1938 \\
1936 \\
1928 \\
1910 \\
1912 \\
1912 \\
1926 \\
1939\end{array}$ \\
\hline $\begin{array}{l}\text { Kirland Lake camp: } \\
\text { Kirkland Minerals } \\
\text { Lakeshore } \\
\text { Macassa } \\
\text { Sylvanite } \\
\text { Teck-Hughes } \\
\text { Toburn } \\
\text { Wright-Hargreaves } \\
\text { Chesterville } \\
\text { Kerr-Addison } \\
\text { Matachewan } \\
\text { Young-Davidson } \\
\text { Queenston } \\
\text { Upper-Canada }\end{array}$ & $\begin{array}{l}\mathbf{F} \\
\mathbf{F} \\
\mathbf{F} \\
\mathbf{F} \\
\mathbf{F} \\
\mathbf{F} \\
\mathrm{K} \\
\mathrm{K} \\
\mathrm{F} \\
\mathrm{F} \\
\mathrm{K} \\
\mathbf{B I F}\end{array}$ & 1263 & $\begin{array}{r}157 \\
\\
\\
182 \\
87 \\
293 \\
566\end{array}$ & & $\begin{array}{l}1919 \\
1918 \\
1933 \\
1927 \\
1917 \\
1913 \\
1913 \\
1939 \\
1938 \\
1934 \\
1934 \\
\\
1938\end{array}$ \\
\hline $\begin{array}{l}\text { Sudbury camp: } \\
\text { Renabie }\end{array}$ & $\mathbf{F}$ & & & & 1947 \\
\hline $\begin{array}{l}\text { Red Lake camp: } \\
\text { Campbell Red Lake } \\
\text { McKenzie Red Lake } \\
\text { Cochenour Willans } \\
\text { Dickenson Red Lake } \\
\text { Madsen Red Lake } \\
\text { Starrat Olsen } \\
\text { Hasaga Red Lake }\end{array}$ & $\begin{array}{l}\mathrm{K} \\
\mathrm{F} \\
\mathrm{BA} \\
\mathrm{K} \\
\mathrm{K} \\
\mathrm{K} \\
\mathrm{K} / \mathrm{F}\end{array}$ & $\begin{array}{r}1435 \\
367 \\
102\end{array}$ & $\begin{array}{r}585 \\
69 \\
179 \\
19 \\
446 \\
115 \\
19-38\end{array}$ & 80 & $\begin{array}{l}1949 \\
1935 \\
1939 \\
1948 \\
1938 \\
1948 \\
1938\end{array}$ \\
\hline $\begin{array}{l}\text { Geraldton-Beardmore: } \\
\text { Hard Rock Gold } \\
\text { Little Long Lac } \\
\text { Macleod-Cockshutt } \\
\text { Magnet Consolidated } \\
\text { Leitch Gold Mine } \\
\text { Theresa }\end{array}$ & $\begin{array}{l}\text { BIF } \\
\text { BIF } \\
\text { BIF } \\
\text { BIF } \\
\text { BIF } \\
\text { F }\end{array}$ & & $\begin{array}{r}128 \\
88 \\
87\end{array}$ & & $\begin{array}{l}1938 \\
1934 \\
1938 \\
1938 \\
1936 \\
1935\end{array}$ \\
\hline $\begin{array}{l}\text { Sioux Lookout camp: } \\
\text { Pickle Crow } \\
\text { New Jason } \\
\text { Central Patricia }\end{array}$ & $\begin{array}{l}\text { F } \\
\text { BIF } \\
\text { BIF }\end{array}$ & & $\begin{array}{l}60-105 \\
59-188\end{array}$ & & $\begin{array}{l}1935 \\
1934 \\
1935\end{array}$ \\
\hline $\begin{array}{l}\text { Sudbury camp (nickel an } \\
\text { Elliot Lake camp (uraniu } \\
\text { Bancroft camp (uranium }\end{array}$ & & & $\begin{array}{l}20 \\
209,28,89\end{array}$ & $5-10$ & \\
\hline
\end{tabular}

BA = Basaltic; $\mathrm{F}=$ Felsic; $\mathrm{BIF}=$ banded iron formation; $\mathrm{K}=$ Komatiite, ultramafic. 
analysis (table 7) supports that impression. The fit between the data and the model with only the term for the time weighted index of exposure to chromium is not different from the fit between the data and the model with both the time weighted duration of employment in gold mines and the time weighted index of exposure to chromium $\left(\chi_{1}^{2} 0 \cdot 12, p=0 \cdot 7\right)$. This analysis indicates that the model which shows an association between the excess of stomach cancer and the time weighted index of exposure to chromium is the preferred one.

Hospital notes or re-examination of carcinomas confirmed the diagnosis of stomach cancer for 73 of the 104 deaths among gold miners where the death certificate indicated stomach cancer as the cause of death.

Tissue samples from 255 stomach cancer cases among Ontario miners were sought. This number

Table 5 Mortality from stomach cancer and time weighted exposure to dust in gold mines, to chromium and arsenic, and time weighted duration of employment in mines containing mineral fibre

\begin{tabular}{|c|c|c|c|c|c|c|c|c|c|}
\hline \multirow{2}{*}{$\begin{array}{l}\text { Time weighted duration of } \\
\text { employment in gold mines }\end{array}$} & \multicolumn{3}{|c|}{ Under age 60} & \multicolumn{3}{|c|}{ Age 60-74 } & \multicolumn{3}{|c|}{ Under age 75} \\
\hline & Obs & $\operatorname{Exp}$ & $S M R$ & Obs & $\operatorname{Exp}$ & $S M R$ & Obs & $\operatorname{Exp}$ & $S M R$ \\
\hline $\begin{array}{l}0 \\
0-4 \\
4-8 \\
8-12 \\
\geqslant 12 \\
\chi^{2} \text { for linear trend } \\
\mathrm{p} \text { Value }\end{array}$ & $\begin{array}{r}5 \\
9 \\
10 \\
9 \\
12\end{array}$ & $\begin{array}{l}5 \cdot 50 \\
7 \cdot 15 \\
4 \cdot 92 \\
3 \cdot 73 \\
5 \cdot 67 \\
4 \cdot 13 \\
0 \cdot 04\end{array}$ & $\begin{array}{r}91 \\
126 \\
203 \\
242 \\
211\end{array}$ & $\begin{array}{r}17 \\
8 \\
10 \\
7 \\
17\end{array}$ & $\begin{array}{c}11 \cdot 12 \\
6.83 \\
5 \cdot 73 \\
5.87 \\
11 \cdot 72 \\
0.004 \\
0.9\end{array}$ & $\begin{array}{l}153 \\
117 \\
175 \\
119 \\
145\end{array}$ & $\begin{array}{l}22 \\
17 \\
20 \\
16 \\
29\end{array}$ & $\begin{array}{l}16.61 \\
13.98 \\
10.65 \\
9.59 \\
17.39 \\
1.31 \\
0.3\end{array}$ & $\begin{array}{l}132 \\
122 \\
188 \\
167 \\
167\end{array}$ \\
\hline $\begin{array}{l}\text { Time weighted index of } \\
\text { exposure to chromium }\end{array}$ & Obs & $\operatorname{Exp}$ & $S M R$ & Obs & $\operatorname{Exp}$ & $S M R$ & Obs & $\operatorname{Exp}$ & $S M R$ \\
\hline $\begin{array}{l}0 \\
0-0.03 \\
0 \cdot 03-0 \cdot 1 \\
0 \cdot 1-0 \cdot 3 \\
\geqslant 0 \cdot 3 \\
\chi^{2}{ }_{1} \text { for linear trend } \\
\mathrm{p} \text { Value }\end{array}$ & $\begin{array}{r}5 \\
8 \\
7 \\
14 \\
11\end{array}$ & $\begin{array}{l}5 \cdot 52 \\
4 \cdot 43 \\
6 \cdot 59 \\
8 \cdot 04 \\
2 \cdot 38 \\
9 \cdot 28 \\
0 \cdot 0002\end{array}$ & $\begin{array}{r}91 \\
180 \\
106 \\
174 \\
463\end{array}$ & $\begin{array}{r}17 \\
4 \\
14 \\
18 \\
6\end{array}$ & $\begin{array}{r}11 \cdot 13 \\
4 \cdot 71 \\
9 \cdot 35 \\
12 \cdot 64 \\
3 \cdot 44 \\
0 \cdot 24 \\
0 \cdot 6\end{array}$ & $\begin{array}{r}153 \\
85 \\
150 \\
142 \\
175\end{array}$ & $\begin{array}{l}22 \\
12 \\
21 \\
32 \\
17\end{array}$ & $\begin{array}{r}16 \cdot 65 \\
9 \cdot 14 \\
15 \cdot 94 \\
20 \cdot 68 \\
5 \cdot 82 \\
6 \cdot 15 \\
0 \cdot 01\end{array}$ & $\begin{array}{l}132 \\
131 \\
132 \\
155 \\
295\end{array}$ \\
\hline $\begin{array}{l}\text { Time weighted index of } \\
\text { exposure to arsenic }\end{array}$ & Obs & $\operatorname{Exp}$ & $S M R$ & Obs & $\operatorname{Exp}$ & $S M R$ & Obs & $\operatorname{Exp}$ & $S M R$ \\
\hline $\begin{array}{l}0 \\
0-0 \cdot 1 \\
0 \cdot 1-0 \cdot 3 \\
0 \cdot 3-1 \cdot 0 \\
\geqslant 1 \cdot 0 \\
\chi^{2} \text { for linear trend } \\
p \text { Value }\end{array}$ & $\begin{array}{r}5 \\
8 \\
4 \\
14 \\
14\end{array}$ & $\begin{array}{l}5 \cdot 52 \\
3 \cdot 87 \\
4 \cdot 54 \\
6 \cdot 36 \\
6 \cdot 68 \\
1.56 \\
0 \cdot 2\end{array}$ & $\begin{array}{r}91 \\
207 \\
88 \\
220 \\
210\end{array}$ & $\begin{array}{r}17 \\
7 \\
4 \\
18 \\
13\end{array}$ & $\begin{array}{r}11 \cdot 13 \\
4 \cdot 18 \\
6 \cdot 26 \\
8 \cdot 25 \\
11 \cdot 43 \\
0 \cdot 55 \\
0 \cdot 5\end{array}$ & $\begin{array}{r}153 \\
167 \\
64 \\
218 \\
114\end{array}$ & $\begin{array}{r}22 \\
15 \\
8 \\
32 \\
27\end{array}$ & $\begin{aligned} 16 \cdot 65 \\
8 \cdot 05 \\
10 \cdot 80 \\
14 \cdot 62 \\
18 \cdot 11 \\
0.06 \\
0.8\end{aligned}$ & $\begin{array}{r}132 \\
186 \\
74 \\
219 \\
149\end{array}$ \\
\hline $\begin{array}{l}\text { Time weighted duration of } \\
\text { employment in mines } \\
\text { containing mineral fibres }\end{array}$ & Obs & $\operatorname{Exp}$ & $S M R$ & Obs & $\operatorname{Exp}$ & $S M R$ & Obs & $\operatorname{Exp}$ & $S M R$ \\
\hline $\begin{array}{l}0 \\
0-4 \\
4-8 \\
8-12 \\
\geqslant 12 \\
\chi_{1}^{2} \text { for linear trend } \\
p \text { Value }\end{array}$ & $\begin{array}{r}28 \\
4 \\
8 \\
2 \\
3\end{array}$ & $\begin{array}{c}18 \cdot 19 \\
4 \cdot 38 \\
2 \cdot 15 \\
1 \cdot 12 \\
1 \cdot 12 \\
2 \cdot 38 \\
0 \cdot 1\end{array}$ & $\begin{array}{r}154 \\
91 \\
373 \\
178 \\
268\end{array}$ & $\begin{array}{r}44 \\
5 \\
1 \\
3 \\
6\end{array}$ & $\begin{array}{c}32 \cdot 25 \\
3.11 \\
1.95 \\
1.67 \\
2.28 \\
1.15 \\
0.3\end{array}$ & $\begin{array}{r}136 \\
161 \\
51 \\
180 \\
263\end{array}$ & $\begin{array}{r}72 \\
9 \\
9 \\
5 \\
9\end{array}$ & $\begin{array}{r}50 \cdot 44 \\
7 \cdot 49 \\
4 \cdot 10 \\
2 \cdot 79 \\
3 \cdot 40 \\
3 \cdot 32 \\
0 \cdot 07\end{array}$ & $\begin{array}{l}143 \\
120 \\
220 \\
179 \\
265\end{array}$ \\
\hline
\end{tabular}

Table 6 Mortality from stomach cancer in gold miners under the age of 60 by time weighted duration of employment in gold mines and time weighted index of exposure to chromium

\begin{tabular}{|c|c|c|c|c|c|c|c|c|c|}
\hline \multirow{3}{*}{$\begin{array}{l}\text { Time weighted duration } \\
\text { of employment in } \\
\text { gold mines }(y) \text {.. }\end{array}$} & \multicolumn{9}{|c|}{ Time weighted index of exposure to chromium (\%Cr-y) } \\
\hline & \multicolumn{3}{|c|}{$<0.1 \% C r-y$} & \multicolumn{3}{|c|}{$\geqslant 0.1 \% C r-y$} & \multicolumn{3}{|c|}{ Total } \\
\hline & Obs & $\operatorname{Exp}$ & $S M R$ & Obs & $\operatorname{Exp}$ & $S M R$ & Obs & $\operatorname{Exp}$ & $S M R$ \\
\hline $\begin{array}{l}<8 \\
\geqslant 8 \\
\text { Total }\end{array}$ & $\begin{array}{r}16 \\
4 \\
20\end{array}$ & $\begin{array}{r}14.59 \\
1.95 \\
16.55\end{array}$ & $\begin{array}{l}110 \\
205 \\
121\end{array}$ & $\begin{array}{r}8 \\
17 \\
25\end{array}$ & $\begin{array}{r}2.97 \\
7 \cdot 45 \\
10 \cdot 42\end{array}$ & $\begin{array}{l}269 \\
228 \\
240\end{array}$ & $\begin{array}{l}24 \\
21 \\
45\end{array}$ & $\begin{array}{r}17 \cdot 56 \\
9 \cdot 40 \\
26.96\end{array}$ & $\begin{array}{l}137 \\
223 \\
167\end{array}$ \\
\hline
\end{tabular}


includes the members of the study group and other miners known to have died of stomach cancer but who did not meet the conditions for entry to the study. In 46 gold miners with gastric cancer, and in 24 other miners, tissue was obtained to confirm the diagnosis histologically. Table 8 shows the findings together with the findings in a control series of 110 cases of gastric cancer in men, treated in Toronto in the General Division of the Toronto Hospital or in Mount Sinai Hospital. The table shows the frequency of each type of carcinoma and for gold

Table 7 Poisson regression: time weighted duration of employment in gold mines and time weighted index of exposure to chromium

\begin{tabular}{|c|c|c|c|c|}
\hline \multicolumn{3}{|c|}{ Regression coefficients } & \multirow[b]{2}{*}{ Deviance } & \multirow{2}{*}{$\begin{array}{l}\text { Degrees } \\
\text { of freedom }\end{array}$} \\
\hline$i$ & $a^{\prime \prime}$ & $c$ & & \\
\hline $\begin{array}{l}1.67 \\
1.11 \\
1.02 \\
1.06\end{array}$ & $\begin{array}{r}0.095 \\
-0.022\end{array}$ & $\begin{array}{l}5.91 \\
6.70\end{array}$ & $\begin{array}{l}23.93 \\
20 \cdot 11 \\
14.90 \\
14 \cdot 78\end{array}$ & $\begin{array}{l}17 \\
16 \\
16 \\
15\end{array}$ \\
\hline
\end{tabular}

Full model: Obs/Exp $=\mathrm{i}+\mathrm{d}$ DST + c CR where: Obs $=$ observed number of stomach cancer deaths; Exp = expected number of stomach cancer deaths; DST = time weighted duration of employment in gold mines; $\mathrm{CR}=$ time weighted index of exposure to chromium. miners, the average index of exposure to chromium five to 19 years before death. Although only a few tissue samples from cases of gastric cancer could be found and classified using the Laurén system, the data do suggest an association between the intestinal type of gastric cancer in miners under the age of 60 years and exposure to chromium in the gold mines.

\section{Discussion}

GASTRIC CANCER MORTALITY IN OTHER MINERS

Table 9 records the observed and expected numbers of gastric cancer cases in other studies of the incidence of gastric carcinoma in miners.

Some published reports record an excess of gastric cancer. An excess of stomach cancer in iron ore miners in Cumbria was not completely explained by social class. ${ }^{10}$ An excess in iron ore miners in Minnesota appeared to be confined to miners born in Finland. ${ }^{11}$ Findings in Cornish tin miners have been inconsistent. An initial report noted an excess of gastric cancer; ${ }^{12}$ a subsequent report could detect no such excess but noted an excess in surface workers from a calcining plant. ${ }^{13}$ No excess of gastric cancer was found in iron ore miners in the Lorraine, but there was a numerical excess in men between 40 and

Table 8 Histological classification of stomach cancers in gold miners and control series

\begin{tabular}{|c|c|c|c|c|c|c|c|c|}
\hline \multirow{2}{*}{$\begin{array}{l}\text { Age } \\
\text { group } \\
(y)\end{array}$} & \multirow[b]{2}{*}{$\begin{array}{l}\text { Histological } \\
\text { classification }\end{array}$} & \multicolumn{3}{|c|}{ Gold miners } & \multicolumn{2}{|c|}{ Other miners } & \multicolumn{2}{|c|}{ Control series } \\
\hline & & No & $(\%)$ & $\begin{array}{l}\text { Mean time weighted index of } \\
\text { exposure to chromium }(\% \text { Cr-y) }\end{array}$ & No & $(\%)$ & No & $(\%)$ \\
\hline$<60$ & $\begin{array}{l}\text { Diffuse } \\
\text { Intestinal } \\
\text { Mixed } \\
\text { Total reclassified } \\
\text { No tumour in tissue sample } \\
\text { Unclassifiable } \\
\text { Not re-examined } \\
\text { Total }\end{array}$ & $\begin{array}{r}1 \\
9 \\
1 \\
11 \\
0 \\
2 \\
37 \\
50\end{array}$ & $\begin{array}{r}(9) \\
(82) \\
(9)\end{array}$ & $\begin{array}{l}0.08 \\
0 \cdot 20 \\
0 \cdot 14 \\
0 \cdot 19 \\
\\
0 \cdot 07 \\
0.51 \\
0.41\end{array}$ & $\begin{array}{r}1 \\
2 \\
1 \\
4 \\
1 \\
4 \\
41 \\
50\end{array}$ & $\begin{array}{l}(25) \\
(50) \\
(25)\end{array}$ & $\begin{array}{r}9 \\
13 \\
6\end{array}$ & $\begin{array}{l}(32) \\
(46) \\
(21)\end{array}$ \\
\hline$\geqslant 60$ & $\begin{array}{l}\text { Diffuse } \\
\text { Intestinal } \\
\text { Mixed } \\
\text { Total reclassified } \\
\text { No tumour in tissue sample } \\
\text { Unclassifiable } \\
\text { Not reexamined } \\
\text { Total }\end{array}$ & $\begin{array}{r}9 \\
15 \\
4 \\
28 \\
3 \\
6 \\
61 \\
98\end{array}$ & $\begin{array}{l}(32) \\
(54) \\
(14)\end{array}$ & $\begin{array}{l}0 \cdot 39 \\
0 \cdot 16 \\
0 \cdot 05 \\
0 \cdot 21 \\
0 \cdot 21 \\
0 \cdot 08 \\
0 \cdot 21 \\
0 \cdot 20\end{array}$ & $\begin{array}{r}4 \\
9 \\
1 \\
14 \\
1 \\
2 \\
40 \\
57\end{array}$ & $\begin{array}{r}(29) \\
(64) \\
(7)\end{array}$ & $\begin{array}{l}25 \\
43 \\
14\end{array}$ & $\begin{array}{l}(30) \\
(52) \\
(17)\end{array}$ \\
\hline
\end{tabular}

Table 9 Mortality from gastric cancer in other miners

\begin{tabular}{|c|c|c|c|c|c|}
\hline Group of miners & $\begin{array}{l}\text { Type of mortality } \\
\text { statistic }\end{array}$ & Obs & $\operatorname{Exp}$ & Obs/Exp (\%) & $95 \% C I$ \\
\hline $\begin{array}{l}\text { Iron ore, Lorraine, all ages }{ }^{14} \\
\text { Iron ore, Lorraine, aged 40-49 } \\
\text { Iron ore, Cumbria } \\
\text { Iron ore, Minnesota }^{11} \\
\text { Gold, South Africa }^{15} \\
\text { Gold, Salsigne }^{16} \\
\text { Gold, western Australia }^{19} \\
\text { Tin, Cornwall } \\
\text { Tin, Cornwall }\end{array}$ & $\begin{array}{l}\text { PMR } \\
\text { PMR } \\
\text { SMR } \\
\text { SMR } \\
\text { SMR } \\
\text { SMR } \\
\text { SMR } \\
\text { SMR } \\
\text { SMR }\end{array}$ & $\begin{array}{r}25 \\
4 \\
25 \\
77 \\
11 \\
3 \\
4 \\
10 \\
27\end{array}$ & $\begin{array}{c}26 \cdot 6 \\
1 \cdot 22 \\
16 \cdot 34 \\
46 \cdot 1 \\
7 \cdot 0 \\
1 \cdot 96 \\
9 \cdot 8 \\
5 \cdot 0 \\
19 \cdot 1\end{array}$ & $\begin{array}{r}94 \\
327 \\
153 \\
167 \\
157 \\
153 \\
40 \\
200 \\
141\end{array}$ & $\begin{array}{r}61-139 \\
89-839 \\
99-226 \\
132-209 \\
78-281 \\
32-447 \\
11-105 \\
96-206 \\
93-206\end{array}$ \\
\hline
\end{tabular}


49 years old. ${ }^{14}$ The arsenic in the mines in Lorraine ranged between $0.02 \%$ and $0.05 \%$ and the chromium between 65 and $160 \mathrm{ppm}$.

No excess of gastric cancer could be detected in white, middle aged gold miners in South Africa, ${ }^{15}$ or in gold miners in Salsigne ${ }^{16}$ and western Australia. ${ }^{17}$

DIET, SMOKING, ALCOHOL, AND PLACE OF BIRTH

Many studies of stomach cancer indicate asociations between diet and the development of stomach cancer with some foods being protective and other foods increasing the incidence of the disease. ${ }^{18}$ Hospital records contain little information about the dietary habits of cases of stomach cancer and it is difficult to contact next of kin retrospectively to obtain such information. Hence, although diet is thought to be an important risk factor for incidence of stomach cancer, it was not possible to take dietary habits into account in this study.

Smoking and alcohol consumption have been shown to affect mortality from stomach cancer. Ontario miners' mortality for cirrhosis of the liver (obs 189, SMR 77, 95\% CI 66-88), however, suggest that the alcohol consumption of Ontario miners is less than that of other men in Ontario. The results of a survey of Ontario gold and nickel and copper miners indicate that there is no difference in smoking habits between these two groups. ${ }^{4}$ Hence, it seems that smoking and alcohol consumption are not likely explanations for the increased mortality from stomach cancer in Ontario gold miners.

Other studies have shown that in comparison to Ontario men born in Canada, there are excesses of stomach cancer in Ontario residents who were born in Great Britain (SMR 159, 95\% CI 145-174), Italy (SMR 189, 95\% CI 155-228), The Netherlands (SMR 228, 95\% CI 159-309), Poland (SMR 183, 95\% CI 151-222), and the Soviet Union (SMR 161, 95\% CI 131-196). ${ }^{14}$ The excess in foreign born residents of Ontario is similar to that which occurs after the age of 60 in miners born overseas.

The nickel and copper, gold, and uranium mines are located in the northern part of Ontario where mortality from stomach cancer in men is increased compared with the rest of the province. Data supplied by the Ontario Cancer Treatment and Research Foundation showed that mortality from stomach cancer in the years 1974 to 1986 was $27 \%$ higher (95\% CI $21-33 \%)$ in northern Ontario men than in men in Ontario. This suggests that mortality from stomach cancer for gold miners ought to have been compared with that of men living in northern Ontario. It should be noted, however, that many of the men in northern Ontario worked in the mines and no excess of gastric carcinoma relative to the male population in the whole of Ontario was evident in northern Ontario miners who mined nickel and copper or uranium only.
An excess of gastric cancer within five years of first mining in Ontario (obs 4, SMR 510, 95\% CI 1401313) was apparent among north American born miners who did not mine gold in Ontario. Before mining in Ontario, two of the four miners mined gold in the Province of Quebec and a third worked in a base metal mine there.

The excess of gastric carcinoma in Ontario gold miners cannot be explained by place of birth alone. There was an excess of gastric cancer in Ontario gold miners who were born in north America, as well as in those born overseas. The data suggest that two factors operate to increase the incidence of gastric cancer in Ontario miners. One of these factors affects only gold miners, affects men born in north America and those born overseas, and causes an excess of gastric carcinoma that occurs five to 19 years after beginning gold mining. The other affects only men born overseas, and causes an excess that becomes apparent only after the age of 60 .

EXPOSURE TO BLASTING FUMES, ALUMINIUM POWDER, AND DIESEL EXHAUST FUMES

Previous results showed that increased mortality from stomach cancer could be detected only in miners who began gold mining after $1945 .^{2}$ This suggested that a change in the working conditions in the gold mines after the mid-1940s was responsible for the excess of stomach cancer among Ontario gold miners.

Several changes did occur in the work environment after the mid-1940s but no change was unique to the gold mining industry. The type of explosives changed in all mines in the 1950s and again in the 1970 s but these changes occurred in all mines at about the same times. Aluminium prophylaxis was used in the gold mines and uranium mines in an attempt to decrease the risk of developing silicosis. Diesel powered equipment was introduced in both large nickel and copper mines, some gold mines, and most uranium mines. Most gold mines did not begin using diesel powered equipment until the end of the 1960s. None of these changes explains the early increase in mortality from gastric carcinoma in gold miners.

The association between the excess of stomach cancer and starting gold mining after 1945 can be interpreted as an artefact of the strong associations between the relative excess of mortality from stomach cancer, and both age and time since first gold mining. The mortality in the younger age groups of the miners who first worked in gold mines before 1945 would be only a small part of the mortality from stomach cancer seen in these miners. It should also be noted that of the 10 major gold mines containing ultramafic host rocks, the rocks containing high concentrations of chromium, one began operations in 1912, five started operations between 1938 and 1940, 
and three started operations in 1948 or 1949 . By comparison, 11 of the 32 other gold mines that do not contain ultramafic host rock began operating before 1930 and 20 began operating in the 1930s. Hence, miners who first mined gold after 1945 were more likely to be exposed to high concentrations of chromium than those who started mining gold earlier.

\section{EXPOSURE TO DUST AND CHROMIUM}

Excess mortality from gastric cancer in men exposed to metal or mineral dusts in other industries has been reported. A recent analysis of 137 cases of stomach cancer in the Los Angeles Cancer Registry has shown an association between adenocarcinoma of the stomach in men under the age of 55 and exposure to metal dusts after the associations between stomach cancer and ethnic origin, diet, social class, smoking, and alcohol consumption were taken into account. ${ }^{20}$ An analysis of 1342 cases of stomach cancer obtained from the same cancer registry has shown an association between adenocarcinomas in the antrum and pylorus and occupations where there were exposures to mineral and organic dusts. ${ }^{21}$ One study of workers in a tyre factory reported an excess of stomach cancer that was largest in the 10 to 19 years after first employment in that industry and seemed to be related to exposure to dust rather than fumes or solvents. ${ }^{22}$

Several studies have suggested that there may be an association between exposure to chromium and mortality from stomach cancer. One study of men who manufactured chromate pigments showed an association between mortality from lung cancer and duration of exposure to chromate dusts in the interval 30 or more years from first employment and suggested a very weak association between duration of exposure to chromate pigments and mortality from stomach cancer. ${ }^{23}$ Hygiene data in the later years showed that highly exposed workers were exposed to $2 \mathrm{mg}$ chromium $/ \mathrm{m}^{3}$ air. A study of cement workers has shown an excess of stomach cancer (SMR 175, 95\% CI 109-264). ${ }^{24}$ The cement workers with high exposures to dust were at greater risk (SMR 238, $95 \%$ CI 123-416) than those with low exposure (SMR 133, 95\% CI 64-245). Cement often contains chromium in the hexavelant form. ${ }^{25}$ Another study, however, has shown an association between employment in jobs where exposure to silica occurred and stomach cancer ${ }^{26}$ but could not find an association between stomach cancer and exposure to cement dust.

The index of exposure to chromium could be regarded as a poor surrogate for measures of exposure to chromium based on air sampling data but that may not be the case here. The amount of dust swallowed by a miner is probably dependent in part on the amount of airborne dust in the mining environment and on the miner's work practices. A large fraction of the airborne dust is cleared from the lung and the nasal passages and then swallowed, but hand to mouth contact is also another route of exposure to dust. The indices of exposure to arsenic and chromium may well be good estimates of the exposure of the stomach to these substances.

The usual approach to examining the relation between a disease and exposure in the workplace is to attempt to relate the increased mortality to the total cumulative amount of exposure to the hazardous substance. Such an approach assumes that the risk from each increment of exposure persists at the same intensity for all periods after the exposure. In the analysis presented here, it is assumed that the risk from each increment of exposure is expressed in a finite amount of time. A similar approach has been used to analyse the combined effect of amount of exposure to radon progeny and the time since exposure in uranium miners. ${ }^{27}$ That analysis, of mortality from lung cancer, showed that the largest increase in risk occurred within 15 years from exposure to short lived radon progeny and that the risk was age dependent with younger miners being at higher risk than older miners.

A previous study showed that an excess of lung cancer in Ontario miners was probably related to exposure to arsenic and short lived radon progeny and that it was unlikely that exposure to mineral fibre was responsible for the excess. Although exposure to chromium compounds was not specifically considered, the concentration of chromium is highest in those gold mines that contain mineral fibre. No excess of lung cancer was associated with the duration of employment in Ontario gold mines containing mineral fibre. Also, other studies have shown strong associations between the incidence of lung cancer and exposure to sparingly soluble hexavalent forms of chromium but only weak and inconsistent associations between the incidence of lung cancer and exposure to other forms of chromium. ${ }^{28}$

\section{Conclusions}

An excess of carcinoma of the stomach was evident in Ontario gold miners. In men under 60, the excess was apparent both in men born in north America and in those born elsewhere. No such increase was evident in other Ontario miners under the age of 60 . In miners over 60 , no excess was apparent in miners born in north America, but an excess was evident in both gold and other miners born elsewhere. This late increase is similar to the excess of gastric carcinoma evident in residents of Ontario born in Europe. The early excess of gastric cancer in the gold miners may be the result of exposure to dust. Chromium may then be the causative agent, or closely associated with it. 
The Ontario Ministry of Labour, the Workers' Compensation Board of Ontario, and the Atomic Energy Control Board provided the funds for this study.

Ms Irene Rule was indispensable in keeping track of the data and Ms Rose Pagliaro assisted in data entry. Mr Colin Benjamin and Ms Elizabeth Grosselfeuger coordinated the review of the tissue samples. Access to the death records at the National Centre for Health Information at Statistics Canada was permitted by the Registrars General of each Province and Territory in Canada.

Cooperation in locating hospital records was provided by the Ontario Cancer Treatment and Research Foundation, the British Columbia Cancer Control Agency, Alberta Cancer Agency, the Saskatchewan Cancer Foundation, Manitoba Cancer Treatment and Research Foundation, Ministère de la Santé et des Services Sociaux du Québec, New Brunswick Tumour Registry, and the Cancer Treatment and Research Foundation of Nova Scotia.

1 Muller J, Wheeler WC, Gentleman JF, Suranyi G, Kusiak RA Study of mortality of Ontario miners, 1955-1977, Part 1. Toronto: Ontario Ministry of Labour, Ontario Workers Compensation Board, Atomic Energy Control Board, 1983.

2 Muller J, Kusiak RA, Suranyi G, Ritchie AC. Study of mortality of Ontario gold miners 1955-1977 addendum. Toronto: Ontario Ministry of Labour, Ontario Workers' Compensation Board, Atomic Energy Control Board, 1987.

3 Industrial Diseases Standards Panel. Report to the Workers' Compensation Board on the Ontario Gold Mining Industry. Toronto: Ontario Ministry of Labour, 1987.

4 Kusiak RA, Springer J, Ritchie AC, Muller J. Lung cancer in Ontario gold miners: possible aetiological factors: $\mathrm{Br} J$ Ind Med 1991;48:808-17.

5 Colvine AC, Fyon JA, Heather KB, Marmont S, Smith PM, Troop DG. Archean lode gold deposits in Ontario. Toronto: Queen's Printer for Ontario, 1988. (Ontario Geological Survey, miscellaneous paper No 139).

6 Garcia MM, Harplani S. Distribution and Characterization by detonation of explosives in an underground mine. Mining Science and Technology 1989;8:49-58.

7 Laurén P. The two histological main types of gastric carcinoma. Diffuse and so called intestinal carcinoma. Acta Patholica et Microbiol Scandinavica 1965;64:31-49.

8 Watanabe H, Jass JR, Sobin LH. Histological typing of oesophageal and gastric tumours. Berlin: Springer-Verlag, 1990.

9 Langard S. Biological and environmental aspects of chromium. Amsterdam: Elsevier Biomedical Press, 1982.
10 Kinlen LJ, Willows AN. Decline in the lung cancer hazard: a prospective study of the mortality of iron ore miners in Cumbria. Br J Ind Med 1988;45:219-24.

11 Lawler AB, Mandel JS, Schumna LM, Lubin JH. A retrospective cohort mortality study of iron ore (hematite) miners in Minnesota. J of Occup Med 1985;27:507-17.

12 Fox AJ, Goldblatt P, Kinlen LJ. A Study of the mortality of Cornish tin miners. Br J Ind Med 1981;38:378-80.

13 Hodgson JT, Jones RD. Mortality of a cohort of tin miners 1941-86. Br J Ind Med 1990;47:665-76.

14 Mur, J-M, Meyer-Busch C, Pham QT, et al. Risk of lung cancer among iron ore miners: a proportional mortality study of 1075 deceased miners in Lorraine, France. J Occup Med 1987;29:762-8.

15 Wyndham $\mathrm{CH}$, Bezuidenhout $\mathrm{BN}$, Greenacre $\mathrm{MJ}$, SluisCremer GK. Mortality of middle aged white South African gold miners. $\mathrm{Br} J$ Ind Med 1986;43:677-84.

16 Simonato L, Ferro G, Winkelman R, Saracci R. A mortality study of miners and factory workers at the "societe des mines et produits chimiques de Salsigne", France. Lyon, France: International Agency for Research on Cancer, World Health Organisation.

17 Armstrong BK, McNulty JC, Levitt LJ, Williams KA, Hobbs MS. Mortality in gold and coal miners in Western Australia with special reference to lung cancer. $\mathrm{Br} J$ Ind Med 1979;36:199-205.

18 Bulatti E, Palli D, Bianchi S, Decarli A, et al. A case-control study of gastric cancer and diet in Italy. III. Risk patterns by histologic type. Int J Cancer 1991;48:369-74.

19 Newman AM, Spengler RF. Cancer mortality among immigrant populations in Ontario, 1969 through 1973. Can Med Asoc J 1984;130:399-405.

20 Wu-Williams AH, Yu MC, Mack TM. Life-style, workplace and stomach cancer by subsite in young men of Los Angeles county. Cancer Res 1990;50:2569-76.

21 Wright WE, Bernstein L, Peters JM, Garabrant DH, Mack TM. Adenocarcinoma of the stomach and exposure to occupational dust. Am J Epidemiol 1988;128:64-73.

22 Sorahan T, Parkes HG, Veys CA, Waterhouse JAH. Cancer mortality in the British rubber industry: $1946-80 . \mathrm{Br} J$ Ind Med 1986;43:363-73.

23 Hayes RB, Sheffet A, Spiritas R. Cancer mortality among a cohort of chromium pigment workers. Am J Ind Med 1989;16:127-33.

$24 \mathrm{McDowall} \mathrm{ME}, \mathrm{A}$ mortality study of cement workers. $\mathrm{Br} \mathrm{J}$ Ind Med 1984;41:179-82.

25 Cronin E. Contact dermatitis. Edinburgh: Churchill Livingstone, 1980.

26 Siemiatycki J, Dewar R, Lakhani R, Nadon L, Richardson L, Gérin $M$. Cancer risks associated with 10 inorganic dusts: results from a case-control study in Montreal. Am J Ind Med 1989;16:547-67.

27 National Research Council. Report of the Committee on the Biological Effects of Ionizing Radiation: health risks of radon and other internally deposited alpha emitters. National Research Council. National Academy of Sciences, Washington DC: National Academy Press, 1988.

28 Yassi A, Nieboer E. Carcinogenicity of chromium compounds. In: Nriagu JD, Nieboer E, eds. Chromium in the natural environment. New York: John Wiley, 1988.

Accepted 30 March 1992. 